\title{
Effect of carbon source on dissimilatory nitrate reduction to ammonium in coastal wetland sediments
}

\author{
X. Liu ${ }^{1,2}$, J.-G. Han ${ }^{3}$, Z.-W. Ma ${ }^{1,2}$, Q. Wang ${ }^{4}$, L.-H. Li ${ }^{1, *}$ \\ ${ }^{I}$ State Key Laboratory of Desert and Oasis Ecology, Xinjiang Institute of Ecology and Geography, Chinese \\ Academy of Sciences, Urumqi, 830011, Xinjiang, China. ${ }^{2}$ University of Chinese Academy of Sciences, Beijing, \\ 100049, China. ${ }^{3}$ College of Biology and the Environment, Nanjing Forestry University, Nanjing, 210037 , \\ China. ${ }^{4}$ Faculty of Agriculture, Shizuoka University, Shizuoka 422-8529, Japan. \\ "Corresponding author:lilh@ms.xjb.ac.cn
}

\begin{abstract}
${ }^{15} \mathrm{~N}$ tracing technique was applied to investigate the effects of various organic carbon (OC) sources on dissimilatory nitrate $\left(\mathrm{NO}_{3}^{-}\right)$reduction to ammonium $\left(\mathrm{NH}_{4}^{+}\right)$(DNRA) rates in the coastal wetland sediments. Soils collected from the Chongming Dongtan wetland were incubated at $25^{\circ} \mathrm{C}$ in the dark for $24 \mathrm{~h}$ following the additions of OC sources (glucose, acetate, malate, citrate and oxalate $(500 \mu \mathrm{g} \mathrm{C} \mathrm{g}-1$ dry soil $)$ ) and ${ }^{15} \mathrm{~N}$-labeled $\mathrm{NH}_{4}{ }^{15} \mathrm{NO}_{3}$ (initial ${ }^{15} \mathrm{~N}$ atom $\%$ of $\mathrm{NO}_{3}^{-}-\mathrm{N}$ is $20 \%$ ). The results showed that soil DNRA rates varied from $0.018-0.497 \mathrm{mg}$ $\mathrm{N} \mathrm{kg}^{-1}$ dry soil $\mathrm{d}^{-1}$ during the whole incubation, and the rates differed significantly among treatments following the order: oxalate $>$ citrate $>$ glucose $>$ acetate $>$ malate $>$ no exogenous $\mathrm{C}$ addition over the first 12 -h incubation. This was possibly caused by the different decomposition rates of various OC sources, which further influenced the available energy provided for DNRA microorganisms. Soils with no addition of exogenous $\mathrm{C}$ showed low soil DNRA rates, presumably because of the low $\mathrm{C} / \mathrm{NO}_{3}^{-}$ratio as well as energy availability. The relative lower soil DNRA rates over the 24-h incubation indicated that DNRA is a fast process. Our results suggest that DNRA could be controlled by OC sources, especially organic acids, demonstrating that the widespread use of glucose in soil laboratory studies might limit our understanding on the effects of OC on soil DNRA process.
\end{abstract}

Keywords: Dissimilatory nitrate reduction to ammonium, carbon source, ${ }^{15} \mathrm{~N}$ tracing technique, organic acid, coastal wetland

\section{Introduction}

Nitrogen $(\mathrm{N})$ is an essential nutrient affecting biological production in terrestrial and aquatic ecosystems, hence it is important to understand how this element is cycled in a specific region or ecosystem
(Francis et al., 2007; Zhao et al., 2013). Coastal wetlands reside at a critical interface between terrestrial land and ocean, which plays a crucial role in balancing and sequestrating $\mathrm{N}$ as well as protecting 
biodiversity of coastal ecosystems (Bai et al., 2012). $\mathrm{N}$ has been believed to be a major limiting nutrient for plant growth in pristine coastal wetlands. However, an increase in human disturbance along the coast over recent decades has accelerated $\mathrm{N}$ loading into coastal areas via nutrient-rich rivers, groundwater as well as atmospheric $\mathrm{N}$ deposition (Koop-Jakobsen and Giblin, 2010). As a result, coastal ecosystems have always experienced eutrophication, which caused severe environmental problems, such as increased frequencies and magnitudes of phytoplankton blooms and loss of habitats for submerged vascular plants (Rabalais and Nixon, 2002). An improved understanding of $\mathrm{N}$ dynamics in coastal wetlands is needed to maintain regional and global ecological security (Bai et al., 2012).

For a multitude of coastal wetlands, the dominant form of anthropogenic $\mathrm{N}$ inputs is nitrate $\left(\mathrm{NO}_{3}^{-}\right.$) (Burgin and Hamilton, 2007). There are two important $\mathrm{NO}_{3}^{-}$removal pathways in wetland sediments: one is denitrification (DNF), which sequentially reduces $\mathrm{NO}_{3}^{-}$to dinitrogen $\left(\mathrm{N}_{2}\right)$ via nitrite $\left(\mathrm{NO}_{2}^{-}\right)$, nitric oxide (NO) and nitrous oxide $\left(\mathrm{N}_{2} \mathrm{O}\right)$, and the other is dissimilatory $\mathrm{NO}_{3}^{-}$reduction to ammonium $\left(\mathrm{NH}_{4}^{+}\right)$ (DNRA), by which $\mathrm{NO}_{3}^{-}$is reduced to bioavailable $\mathrm{NH}_{4}^{+}$(Zumft, 1997; Rütting et al., 2011). Because of the different productions, DNF has been not only considered as a major pathway of $\mathrm{N}$ loss in soil-plant systems (Gong et al., 2013), but also the major biological process responsible for global increases in atmospheric $\mathrm{N}_{2} \mathrm{O}$ (Baggs, 2008; Morley et al., 2014). In contrast, DNRA conserves $\mathrm{N}$ in soils as $\mathrm{NH}_{4}^{+}$, thus retaining $\mathrm{N}$ levels of soils (Yin et al., 2002; Koop-Jakobsen and Giblin, 2010). For a long time, DNF is considered as the predominant pathway to remove $\mathrm{NO}_{3}^{-}$(Burgin and Hamilton, 2007). However, over the last few decades, applications of ${ }^{15} \mathrm{~N}$ tracer technique and microbial molecular methods have generated growing evidence that DNRA is also an important $\mathrm{N}$ reduction process that cannot be ignored (Giblin et al., 2013). As an example, Giblin et al., (2013) compared the importance of DNF versus DNRA at 55 coastal sites and found that DNRA accounted for more than $30 \%$ of the $\mathrm{NO}_{3}^{-}$ reduction at 26 sites. Consequently, understanding what controls the DNRA process is vital to regulate $\mathrm{N}$ loadings in coastal wetland sediments.

Among various factors influencing DNRA, carbon (C) $/ \mathrm{NO}_{3}^{-}$ratio has been confirmed to be one of the most important drivers regulate DNRA. For example, Tiedje (1988) argued that DNRA was favored when the ratio of labile $\mathrm{C} / \mathrm{NO}_{3}{ }^{-}$was higher, and later studies further verified his hypothesis (Silver et al., 2001; Yin et al., 2001). In addition, as an essential electron donor of DNRA, organic C (OC) modifies the rate of DNRA by supporting respiration or fermentation that influences the population of DNRA bacteria. However, despite this requirement for $\mathrm{OC}$, the regulation of DNRA by OC is poorly understood compared to other soil parameters such as $\mathrm{pH}$, temperature, moisture and redox status (Rütting et al., 2011), and most existing publications only took glucose into consideration (Henderson et al., 2010; Lu et al., 2013). Nevertheless, plant-derived low molecular $\mathrm{C}$ compounds in soils, which are key factors affecting the rhizosphere microbial community, are always ignored (Morley and Baggs, 2010; Morley et al., 2014). Different OC substrates may also have different effects on the activity of enzyme (Morley and Baggs, 2010). Morley and Baggs (2010) proposed that OC may alter the fate of $\mathrm{NO}_{3}{ }^{-}$in soils on the basis of these hypotheses. In addition, Bonin et al. (1999) pointed out that the theoretical energy of various $\mathrm{C}$ substrates was quite different, which probably also affect the DNRA process. Consequently, application of glucose alone may not provide enough oversight of the regulatory factors controlling DNRA. In order to advance understanding with a more realistic perspective, other $\mathrm{C}$ sources, especially the organic acids generated from root exudates and 
the decomposition of organic matter in plant residues, need to be considered to elucidate their unknown influences on DNRA. Under the background of rapid development of coastal economy, understanding the effects of OC on soil DNRA will help formulating appropriate strategies for the reduction of high $\mathrm{N}$ loadings in soils of coastal ecosystems.

In this study, ${ }^{15} \mathrm{~N}$-labelled $\mathrm{NO}_{3}^{-}-\mathrm{N}$ tracer technique was applied to determine the effects of individual additions of different $\mathrm{C}$ sources (glucose, acetate, malate, citrate and oxalate) and no exogenous $\mathrm{C}$ addition (here termed as NC) on DNRA process in sediments of Chongming Dongtan wetland in Changjiang Estuary. The organic acid selected could be released in soils by rhizosphere fungi, root exudates and the decomposition of organic matter in plant residues.

\section{Materials and Methods}

\subsection{Study area}

Chongming Island $\left(31^{\circ} 25^{\prime} \mathrm{N}-31^{\circ} 38^{\prime} \mathrm{N}, 121^{\circ} 50^{\prime} \mathrm{E}-\right.$ $122^{\circ} 05^{\prime}$ ) is the third largest island in China and one of the largest alluvial islands in the world, which is formed by alluvial silt and soil from the upper reaches of Yangtze River (Li et al., 2010). On the eastern end of the island is the Chongming Dongtan wetland, which is the largest and youngest natural tidal flat in the Changjiang Estuary (Zhang et al., 2011). It has a northern subtropical ocean climate, with an average annual temperature of $15.3{ }^{\circ} \mathrm{C}$, while mean monthly temperature ranges from $2.7^{\circ} \mathrm{C}$ in January to $27.6{ }^{\circ} \mathrm{C}$ in August. The mean annual precipitation is $1022 \mathrm{~mm}$, with more than $70 \%$ of the annual rainfall occurring between April and September (Li et al., 2010). The vegetation area of the tidal flat covers $27.51 \mathrm{~km}^{2}$ and the vegetations primarily consists of Phragmites communis and Scirpus mariqueter. However, with its recent rapid spread and growth, the invasive Spartina alterniflora has occupied 33.1\% of the vegetation area, and mainly distributed in the northeast of Chongming Dongtan wetland (Gan et al., 2009).

\subsection{Soil sampling}

Soil samples (0-15 cm depth) were collected from a site covered with Phragmites communis $\left(31^{\circ} 37^{\prime} \mathrm{N}\right.$, $\left.121^{\circ} 42^{\prime} \mathrm{E}\right)$ in Chongming Dongtan wetland in October 2013, and they were transported to the laboratory within $12 \mathrm{~h}$. Once returned to the laboratory the soils were air-dried in the shade and sieved $(\leq 2 \mathrm{~mm})$. The visible plant materials in sieved soils were then removed. It was a silty clay loam (sand $44.18 \%$, silt $55.56 \%$, clay $0.26 \%)$ with a $\mathrm{pH}\left(\mathrm{H}_{2} \mathrm{O}\right)$ of 8.65 , soil organic carbon (SOC) of $8.39 \mathrm{~g} \mathrm{C} \mathrm{kg}^{-1}$ and total nitrogen (TN), $\mathrm{NH}_{4}{ }^{+}-\mathrm{N}$ and $\mathrm{NO}_{3}{ }^{-} \mathrm{N}$ of $1000.00,6.20$ and 3.40 $\mathrm{mg} \mathrm{kg}{ }^{-1}$, respectively.

\subsection{Experimental set-up}

Soil samples (30 g at 5\% gravimetric water content) were packed into $250 \mathrm{~mL}$ Erlenmeyer flasks, and then $60 \mathrm{~mL}$ of deionized water were added into the flasks. The flasks were then capped with breathable films. Afterwards, the flasks were pre-incubated at $25{ }^{\circ} \mathrm{C}$ in the dark for 7 days. As soon as the pre-incubation finished, different OC substrates, including glucose $(\mathrm{GC})$, acetate (AT), malate (ML), citrate (CT) and oxalate (OL), were applied into the flasks and each treatment had 6 flasks. In addition, 6 flasks with no exogenous $\mathrm{C}$ addition (NC) were also included as a control treatment. In order to make all samples the same liquid volume, $10 \mathrm{~mL}$ of OC solutions (19.79 $\mathrm{mM} \mathrm{GC}, 59.38 \mathrm{mM}$ sodium acetate, $29.69 \mathrm{mM}$ sodium malate, $19.79 \mathrm{mM}$ sodium citrate or $59.38 \mathrm{mM}$ sodium oxalate) or $10 \mathrm{~mL}$ deionized water (NC) was added to each treatment. The final $\mathrm{C}$ added in soils 
was equivalent to $500 \mu \mathrm{g} \mathrm{C} \mathrm{g}^{-1}$. After additions of $\mathrm{C}, 1$ $\mathrm{mL}{ }^{15} \mathrm{~N}$-labeled ammonium nitrate $\left(\mathrm{NH}_{4}{ }^{15} \mathrm{NO}_{3}\right)(15.2$ $\mathrm{mM}$ at 30.15 atom $\%$ excess ${ }^{15} \mathrm{~N}$ ) was applied into each flask which resulted in a target ${ }^{15} \mathrm{~N}$ enrichment of $20 \%$ of soil $\mathrm{NO}_{3}^{-}-\mathrm{N}$ pool. All amendments were added to flasks by syringes through the breathable films. Moreover, 3 additional flasks without addition of $\mathrm{C}$ and ${ }^{15} \mathrm{~N}$-labeled were also prepared to measure the contents of organic $\mathrm{N}(\mathrm{ON}), \mathrm{NH}_{4}^{+}-\mathrm{N}$ and $\mathrm{NO}_{3}^{-}-\mathrm{N}$ after pre-incubation, which represented the initial $\mathrm{N}$ contents before the ${ }^{15} \mathrm{~N}$ tracer experiment. Therefore, there were total 39 flasks used in this study.

After all amendments were added, the flasks were immediately incubated in the dark at $25^{\circ} \mathrm{C}$. It is generally believed that DNRA is a fast process (Yin et al., 2002; Lu et al., 2013). In order to make our investigation comparable to previous ones, $12 \mathrm{~h}$ and $24 \mathrm{~h}$ were chosen as the incubation time, thus 3 flasks of each treatment were destructively sampled after 12 and 24 $\mathrm{h}$ incubations, respectively. To extract soil inorganic $\mathrm{N}, 80 \mathrm{~mL}$ of $1.88 \mathrm{M} \mathrm{KCl}$ was added to each flask. Because $60 \mathrm{~mL}$ deionized water and $10 \mathrm{~mL} \mathrm{C}$ solutions had been added into each flask at the start of the pre-incubation, the final $\mathrm{KCl}$ concentration was about $1 \mathrm{M}$. The soil extracts were analyzed for the concentrations as well as ${ }^{15} \mathrm{~N}$ atom\% of inorganic $\mathrm{N}\left(\mathrm{NH}_{4}{ }^{+}-\mathrm{N}\right.$ and $\mathrm{NO}_{3}^{-}-\mathrm{N}$ ). The extracted soils were then washed with deionized water and oven-dried at $60^{\circ} \mathrm{C}$ for the determination of concentrations and ${ }^{15} \mathrm{~N}$ atom $\%$ of TN in the residuals, which was considered to be $\mathrm{ON}$.

\subsection{Soil measurements}

Soil $\mathrm{NH}_{4}^{+}-\mathrm{N}$ and $\mathrm{NO}_{3}^{-}-\mathrm{N}$ concentrations in the extracts were determined colorimetrically by ultraviolet spectrophotometer (UV-2550, Shimadzu Co., Ltd., Kyoto, Japan). Soil TN and ON were measured by semimicro Kjeldahl digestion selenium (Se), copper sulfate $\left(\mathrm{CuSO}_{4}\right)$ and potassium sulfate $\left(\mathrm{K}_{2} \mathrm{SO}_{4}\right)$ as catalysts. SOC was determined by concentrated sulfuric acid $\left(\mathrm{H}_{2} \mathrm{SO}_{4}\right)$ potassium dichromate $\left(\mathrm{K}_{2} \mathrm{Cr}_{2} \mathrm{O}_{7}\right)$ oxidation and subsequent titration. Soil $\mathrm{pH}$ was determined by a combination electrode in the 1:5 soils to water suspension (w:v). Soil water content was determined gravimetrically after subsamples were dried at $105^{\circ} \mathrm{C}$ to a constant weight. The diffusion method (Brooks et al., 1989) was used for extracting soil ${ }^{15} \mathrm{NH}_{4}{ }^{+}-\mathrm{N}$ and ${ }^{15} \mathrm{NO}_{3}^{-}-\mathrm{N}$ while oven-dried soil was directly used for $\mathrm{ON}^{-15} \mathrm{~N}$ atom\% determination. An automated $\mathrm{C}$ and $\mathrm{N}$ analyzer interfaced with an isotope ratio mass spectrometer (Flash EA-Delta V Advantage, ThermoFisher Scientific Co., Ltd., Massachusetts, USA) was used for determining $\mathrm{N}$ isotope ratios.

\subsection{Calculations and statistical analyses}

According to the procedures of Buresh et al., (1978), Chen et al., (1995) and Yin et al., (2002), DNRA rate $\left(d, \mathrm{mg} \mathrm{N} \mathrm{kg}^{-1}\right.$ dry soil $\left.\mathrm{d}^{-1}\right)$ and relative potential of DNRA ( $d$, \%) were calculated using Eqation 1 and Equation 2, respectively:

$$
d=\left[\left(\left[N H_{4}\right]_{t 2} \times f_{t 2}-\left[N H_{4}\right]_{t 1} \times f_{t 1}\right)+\left([O N]_{t 2} \times f_{t 2}{ }^{\prime}-[O N]_{t 1} \times f_{t 1}{ }^{\prime}\right)\right] /\left[100 \times\left(t_{2}-t_{1}\right)\right]
$$

where $\left[\mathrm{NH}_{4}\right]_{\mathrm{t} 1}$ and $\left[\mathrm{NH}_{4}\right]_{12}$ are the soil $\mathrm{NH}_{4}^{+}-\mathrm{N}$ concentrations at time $\mathrm{t}_{1}$ and $\mathrm{t}_{2}\left(\mathrm{mg} \mathrm{N} \mathrm{kg}^{-1}\right.$ dry soil), respectively; $f_{\mathrm{t} 1}$ and $f_{\mathrm{t} 2}$ are the soil $\mathrm{NH}_{4}{ }^{+-}{ }^{15} \mathrm{~N}$ atom $\%$ at time $\mathrm{t}_{1}$ and $\mathrm{t}_{2}(\%)$, respectively; $[\mathrm{ON}]_{\mathrm{t} 1}$ and $[\mathrm{ON}]_{\mathrm{t} 2}$ are soil
ON concentration at time $\mathrm{t}_{1}$ and $\mathrm{t}_{2}\left(\mathrm{mg} \mathrm{N} \mathrm{kg}^{-1}\right.$ dry soil), respectively; $f_{\mathrm{t} 1}$, and $f_{\mathrm{t} 2}$, are the soil $\mathrm{ON}-{ }^{15} \mathrm{~N}$ atom $\%$ at time $t_{1}$ and $t_{2}(\%)$, respectively; $t_{1}$ is the beginning time of incubation and $t_{2}$ is the end time of incubation. 


$$
\left.d^{\prime}=\left[\left(\left[N H_{4}\right]_{t 2} \times f_{t 2}-\left[N H_{4}\right]_{t 1} \times f_{t 1}\right)+\left([O N]_{t 2} \times f_{t 2}{ }^{\prime}-[O N]_{t 1} \times f_{t 1}{ }^{\prime}\right)\right] /\left[\left[N O_{3}\right]_{t 1} \times f_{t 1}{ }^{\prime \prime}-\left[N O_{3}\right]_{t 2} \times f_{t 2}{ }^{\prime \prime}\right) \times 100\right]
$$

where $\left[\mathrm{NH}_{4}\right]_{\mathrm{t} 1},\left[\mathrm{NH}_{4}\right]_{\mathrm{t} 2},[\mathrm{ON}]_{\mathrm{t} 1},[\mathrm{ON}]_{\mathrm{t} 2}, f_{\mathrm{t} 1}, f_{\mathrm{t} 2}, f_{\mathrm{t} 1}, f_{\mathrm{t} 2}$, $\mathrm{t}_{1}$ and $\mathrm{t}_{2}$ are the same as the variables in Equation (1); $\left[\mathrm{NO}_{3}\right]_{\mathrm{t} 1}$ and $\left[\mathrm{NO}_{3}\right]_{12}$ are the soil $\mathrm{NO}_{3}-\mathrm{N}$ concentrations at time $\mathrm{t}_{1}$ and $\mathrm{t}_{2}$ ( $\mathrm{mg} \mathrm{N} \mathrm{kg}^{-1}$ dry soil), respectively; $f_{\mathrm{t} 1}$ ", and $f_{\mathrm{t} 2} "$ are the soil $\mathrm{NO}_{3}{ }^{-15} \mathrm{~N}$ atom $\%$ at time $\mathrm{t}_{1}$ and $\mathrm{t}_{2}$ (\%), respectively. It should be noted that at the beginning of the first incubation stage, natural abundance of ${ }^{15} \mathrm{~N}(0.366 \%)$ was applied to stand for the value of $\mathrm{NH}_{4}+{ }^{+15} \mathrm{~N}$ atom $\%$ and $\mathrm{ON}^{-15} \mathrm{~N}$ atom $\%$, while the value of $\mathrm{NO}_{3}-{ }^{-15} \mathrm{~N}$ atom $\%$ was $20 \%$ which resulted from the additions of $\mathrm{NH}_{4}{ }^{15} \mathrm{NO}_{3}$ and calculated using the Equation (3) as following:

atom $\%=(S \times 0.366 \%+A \times E) /(S+A)$

where atom $\%$ is the value of ${ }^{15} \mathrm{~N}$ enrichment, $\mathrm{S}$ is the concentration of soil nitrate, $0.366 \%$ is the natural abundance of ${ }^{15} \mathrm{~N}$, A is the concentration of nitrate added after OC additions, $\mathrm{E}$ is the abundance of ${ }^{15} \mathrm{~N}$ of added $\mathrm{NO}_{3}^{-}-\mathrm{N}(30.15 \%)$.

To test whether there were differences among treatments in concentrations and ${ }^{15} \mathrm{~N}$ atom\% of various $\mathrm{N}$ fractions, soil DNRA rate as well as relative potential of soil DNRA, one-way analysis of variance (ANOVA) followed by LSD post hoc test was performed using SPSS 16.0 (SPSS Inc., Chicago, USA). The $t$ test was used to examine the differences in soil indexes mentioned-above between 12 -h and 24 -h incubation. OriginPro 8.0 was used for performing figures (OriginLab, USA).

\section{Results}

\subsection{Concentrations and ${ }^{15} \mathrm{~N}$ atom\% of soil $\mathrm{N}$ pools}

After pre-incubation, soil $\mathrm{NH}_{4}^{+}-\mathrm{N}, \mathrm{NO}_{3}^{-}-\mathrm{N}$ and $\mathrm{ON}$ were $10.50 \pm 0.42,4.13 \pm 0.26$ and $942.00 \pm 9.00 \mathrm{mg} \mathrm{N}$ $\mathrm{kg}^{-1}$ dry soil, respectively, and their kinetics over the 24-h tracer experiment were illustrated in Figure 1. Compared with $\mathrm{NC}$, additions of $\mathrm{OC}$ significantly decreased soil $\mathrm{NH}_{4}^{+}-\mathrm{N}$ during both stages $(P<0.05)$ (Figure 1-a). Different soil $\mathrm{NH}_{4}^{+}-\mathrm{N}$ decrements were also detected among five $\mathrm{OC}$ treatments and the order was $\mathrm{OL}>\mathrm{ML}>\mathrm{GC}>\mathrm{AT}>\mathrm{CT}$. In addition, soil $\mathrm{NH}_{4}{ }^{+} \mathrm{N}$ concentrations were significantly lower over the $24-\mathrm{h}$ incubation than that over the 12-h incubation in all treatments $(P<0.05)$. OC treatments also had negative effects on soil $\mathrm{NO}_{3}^{-}-\mathrm{N}$ concentrations, and the lowest value occurred in treatment OL (Figure 1-b). As the incubation went on, soil $\mathrm{NO}_{3}^{-}-\mathrm{N}$ concentrations decreased in spite of the different treatments. Soil ON also decreased under different OC treatments, and showed the same response with inorganic $\mathrm{N}$ (Figure 1-c). Over the first 12-h incubation, soil ON concentrations decreased following the order: $\mathrm{NC}>\mathrm{AT}>\mathrm{OL}>\mathrm{GC}>\mathrm{ML}>\mathrm{CT}$, while the order changed to $\mathrm{OL}>\mathrm{ML}>\mathrm{CT}>\mathrm{AT}>\mathrm{NC}>\mathrm{GC}$ over the second 12-h incubation. For treatments GC, AT, CT and NC, soil ON concentrations over the 24-h incubation were significantly lower in comparison with that of over the 12-h incubation $(P<0.05)$. Nevertheless, significant differences were not observed in treatments $\mathrm{ML}$ and OL $(P>0.05)$.

As shown in Table 1, soil $\mathrm{NH}_{4}^{+}{ }^{+}{ }^{15} \mathrm{~N}$ atom\% increased to $0.470-0.654 \%$ after 12 -h incubation, and the highest and lowest $\mathrm{NH}_{4}{ }_{-}^{+}{ }^{15} \mathrm{~N}$ atom $\%$ were found in treatment $\mathrm{OL}$ and $\mathrm{NC}$, respectively. The second 12-h incubation further increased $\mathrm{NH}_{4}^{+}-{ }^{+15} \mathrm{~N}$ atom $\%$ in all treatments, although the values did not differ significantly in OC treatments between the two incubation stages $(P>0.05)$. Soil $\mathrm{NH}_{4}{ }^{+}{ }^{15} \mathrm{~N}$ atom\% of $\mathrm{OL}$ was significantly higher than those in other treatments $(P<0.05)$. Soil $\mathrm{ON}-{ }^{15} \mathrm{~N}$ atom $\%$ also showed an increasing trend, 
although the increments were lower compared with the natural abundance of $\mathrm{ON}-{ }^{15} \mathrm{~N}$ atom $\%$. During the entire incubation, soil $\mathrm{ON}-{ }^{15} \mathrm{~N}$ atom $\%$ ranged between $0.373 \%$ and $0.407 \%$. On the contrary, significant reductions of ${ }^{15} \mathrm{~N}$ atom\% were detected in soil $\mathrm{NO}_{3}{ }^{-}-\mathrm{N}$ pool. After $24-\mathrm{h}$ incubation, soil $\mathrm{NO}_{3}-{ }^{-15} \mathrm{~N}$ atom $\%$ de- creased to just $0.570-1.270 \%$ in treatments with OC additions, which were lower compared with the initial $\mathrm{NO}_{3}{ }^{-15} \mathrm{~N}$ atom\%. However, these huge reductions did not occur in treatment $\mathrm{NC}$. Furthermore, the $\mathrm{NO}_{3}-{ }^{-15} \mathrm{~N}$ atom $\%$ also differed significantly between the two incubation stages $(P<0.05)$, indicating soil $\mathrm{NO}_{3}{ }^{-15} \mathrm{~N}$ pool was continuously diluted over time.
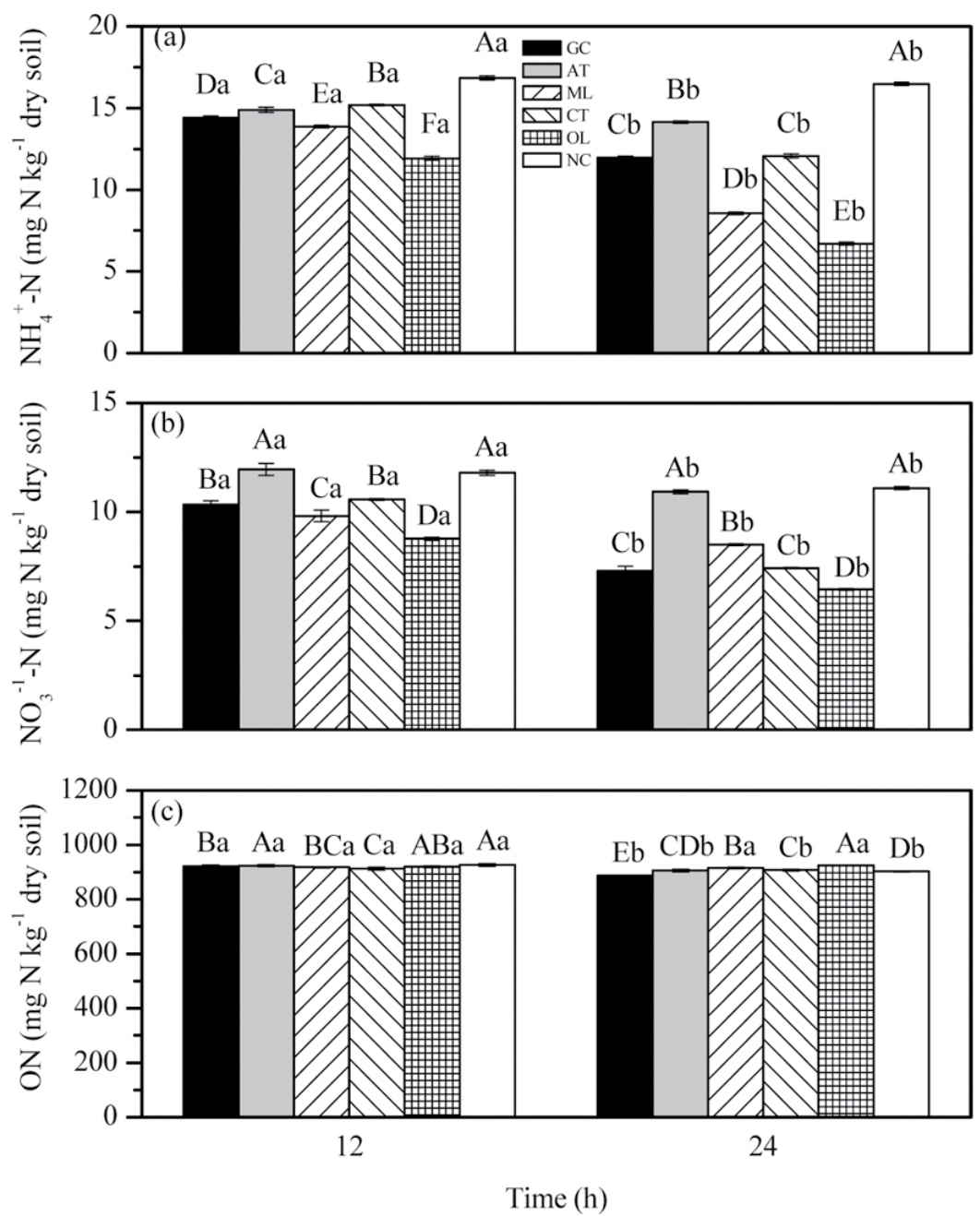

Figure 1. The concentrations of soil $\mathrm{NH}_{4}^{+}-\mathrm{N}$ (a), $\mathrm{NO}_{3}^{-}-\mathrm{N}$ (b) and $\mathrm{ON}$ (c) in sediments of Chongming Dongtan wetland supplied with different forms of OC substrates or none (NC) after 12 and 24-h of incubations. The same uppercase letter indicates values are not significantly different among treatments $(P<0.05)$ within a same incubation period. The same lowercase letter indicates values are not significantly different between two periods $(P<0.05)$ with the same treatment. The error bars stand for standard deviations of the means $(\mathrm{n}=3)$. 
Table 1. ${ }^{15} \mathrm{~N}$ atom\% of various $\mathrm{N}$ fractions in the sediments of Chongming Dongtan wetland supplied with different forms of $\mathrm{OC}$ substrates or none (NC) after 12 and $24 \mathrm{~h}$ of incubations.

\begin{tabular}{|c|c|c|c|c|c|c|}
\hline \multirow[t]{2}{*}{ Treatment } & \multicolumn{2}{|c|}{$\begin{array}{c}\mathrm{NH}_{4}{ }^{+}-{ }^{15} \mathrm{~N} \text { atom } \% \\
(\%)\end{array}$} & \multicolumn{2}{|c|}{$\begin{array}{c}\mathrm{NO}_{3}-{ }^{-15} \mathrm{~N} \text { atom } \% \\
(\%)\end{array}$} & \multicolumn{2}{|c|}{$\begin{array}{c}\mathrm{ON}-^{15} \mathrm{~N} \text { atom } \% \\
(\%)\end{array}$} \\
\hline & $12 \mathrm{~h}$ & $24 \mathrm{~h}$ & $12 \mathrm{~h}$ & $24 \mathrm{~h}$ & $12 \mathrm{~h}$ & $24 \mathrm{~h}$ \\
\hline \multirow[t]{2}{*}{ GC } & $0.537(0.022)^{\mathrm{a}}$ & $0.597(0.035)$ & $8.253(0.136)$ & $0.873(0.175)$ & $0.386(0.002)$ & $0.403(0.001)$ \\
\hline & $\mathrm{Ca}^{\mathrm{b}}$ & $\mathrm{Ba}$ & $\mathrm{Ca}$ & $\mathrm{Bb}$ & $\mathrm{Bb}$ & $\mathrm{Ba}$ \\
\hline \multirow[t]{2}{*}{ AT } & $0.563(0.012)$ & $0.562(0.022)$ & $9.735(0.170)$ & $1.047(0.144)$ & $0.383(0.001)$ & $0.395(0.001)$ \\
\hline & $\mathrm{BCa}$ & $\mathrm{Ba}$ & $\mathrm{Ba}$ & $\mathrm{Bb}$ & $\mathrm{Cb}$ & $\mathrm{Ca}$ \\
\hline \multirow[t]{2}{*}{ ML } & $0.568(0.013)$ & $0.581(0.010)$ & $9.103(0.917)$ & $0.639(0.078)$ & $0.384(0)$ & $0.390(0.001)$ \\
\hline & $\mathrm{Ba}$ & $\mathrm{Ba}$ & $\mathrm{BCa}$ & $\mathrm{Bb}$ & $\mathrm{Cb}$ & $\mathrm{Da}$ \\
\hline \multirow[t]{2}{*}{$\mathrm{CT}$} & $0.587(0.004)$ & $0.588(0.022)$ & $7.171(0.075)$ & $0.606(0.028)$ & $0.400(0.001)$ & $0.407(0.002)$ \\
\hline & $\mathrm{Ba}$ & $\mathrm{Ba}$ & $\mathrm{Da}$ & $\mathrm{Bb}$ & $\mathrm{Ab}$ & Aa \\
\hline \multirow[t]{2}{*}{$\mathrm{OL}$} & $0.654(0.019)$ & $0.706(0.028)$ & $5.142(0.271)$ & $1.065(0.177)$ & $0.401(0)$ & $0.404(0.001)$ \\
\hline & Aa & Aa & $\mathrm{Ea}$ & $\mathrm{Bb}$ & $\mathrm{Ab}$ & $\mathrm{Ba}$ \\
\hline \multirow[t]{2}{*}{$\mathrm{NC}$} & $0.470(0.017)$ & $0.515(0.020)$ & $14.406(0.920)$ & $11.061(1.326)$ & $0.373(0)$ & $0.383(0.001)$ \\
\hline & $\mathrm{Db}$ & $\mathrm{Ca}$ & Aa & $\mathrm{Ab}$ & $\mathrm{Db}$ & Ea \\
\hline
\end{tabular}

${ }^{a}$ Values are means (SD) $(n=3)$.

${ }^{\mathrm{b}}$ The same uppercase letter indicates values are not significantly different among treatments $(P<0.05)$ within a same incubation time. The same lowercase letter indicates values are not significantly different between two periods $(P<0.05)$ with the same treatment.

\subsection{Soil DNRA rate}

Different OC sources significantly affected soil DNRA rates in both incubation stages (Figure 2). Soil DNRA rates varied from 0.018-0.497 mg N $\mathrm{kg}^{-1}$ dry soil $\mathrm{d}^{-1}$, and the maximum and minimum were measured in OL over the 12-h incubation and in AT over the 24-h incubation, respectively. For the first 12-h incubation, the order of DNRA rates followed: $\mathrm{OL}>\mathrm{CT}>\mathrm{GC}>\mathrm{AT}>\mathrm{ML}>\mathrm{NC}$, while soil DNRA rates of GC and AT did not differ significantly $(P>0.05)$. Notably, the mean DNRA rate in soils of $\mathrm{NC}$ was only $0.033 \mathrm{mg} \mathrm{N} \mathrm{kg}{ }^{-1}$ dry soil $\mathrm{d}^{-1}$, which was significantly lower than that in soils with $\mathrm{OC}$ additions $(P<0.05)$. Incubation time also influenced soil DNRA rates: soil DNRA rates over the second 12-h incubation were significantly lower than that over the 12-h incubation in most of the treatments except $\mathrm{NC}(P<0.05)$. During the second incubation stage, soil DNRA rates in treatment OL were not the highest due to their rapid decreases. Instead, the maximum of soil DNRA rates was detected in treatment AT, although its mean value was only $0.074 \mathrm{mg} \mathrm{N} \mathrm{kg}^{-1}$ dry soil $\mathrm{d}^{-1}$. 


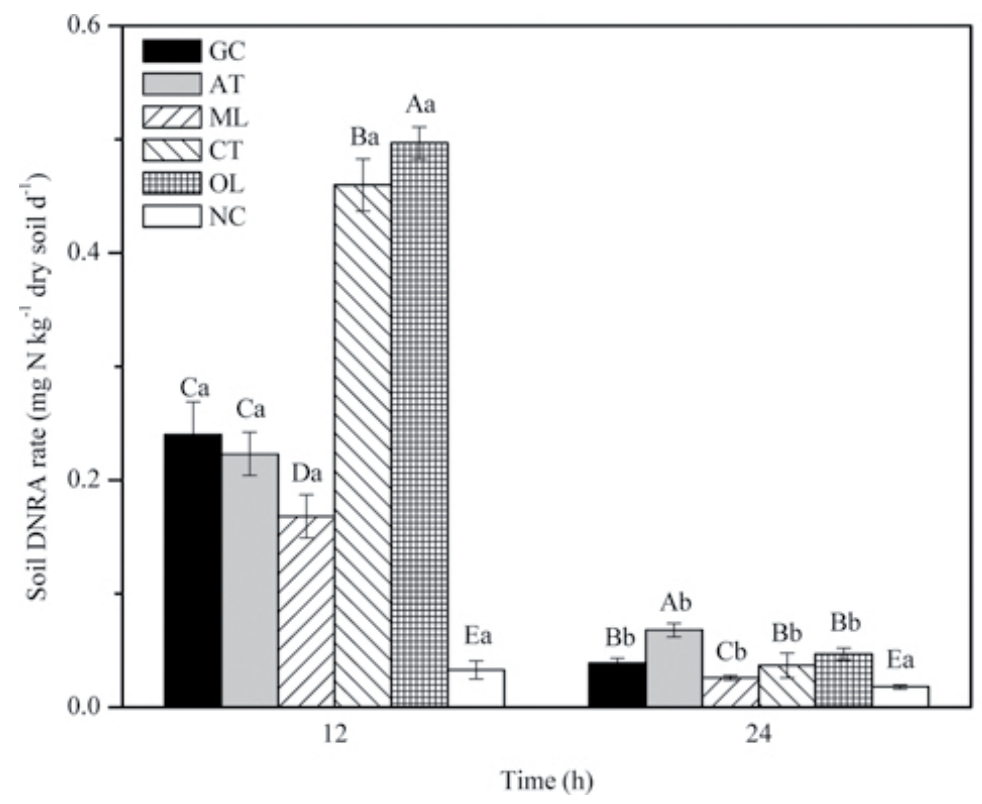

Figure 2. DNRA rates in sediments of Chongming Dongtan wetland supplied with different forms of OC sources or none (NC) over 12 and $24 \mathrm{~h}$ of incubations. The same uppercase letter indicates values are not significantly different among treatments $(P<0.05)$ within a same incubation period. The same lowercase letter indicates values are not significantly different between two periods $(P<0.05)$ with the same treatment. The error bars stand for standard deviations of the means $(n=3)$.

\subsection{Relative potential of soil DNRA}

Relative potential of DNRA, which also refers to the contribution of DNRA to total dissimilatory $\mathrm{NO}_{3}^{-}$reduction, was estimated by the recovery of ${ }^{15} \mathrm{~N}$ in $\mathrm{NH}_{4}^{+}-\mathrm{N}$ and $\mathrm{ON}$ divided by the changes of ${ }^{15} \mathrm{~N}$ in $\mathrm{NO}_{3}^{-}-\mathrm{N}$. As shown in Figure 3, different OC treatments influenced the relative potential of soil DNRA during both incubation stages. For the first 12-h incubation, the relative potential of soil DNRA varied from 4.50-27.57\%, and values ofsoils amended with CT were significant higher than those of $(P<0.05)$, although its soil DNRA rate was not the highest (Figures 2 and 3).

Moreover, similar to the DNRA rate, relative potential of soil DNRA also showed decreasing tendencies in all treatments during the second 12-h incubation. 


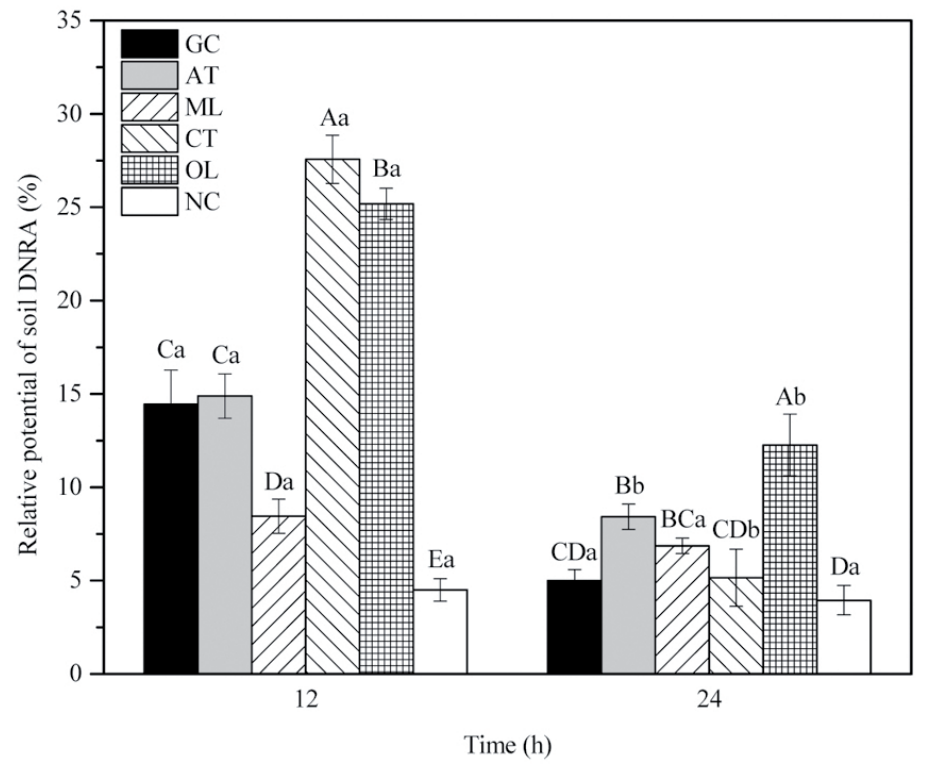

Figure 3. Relative potential of soil DNRA in sediments of Chongming Dongtan wetland supplied with different forms of OC substrates or none (NC) after 12 and $24 \mathrm{~h}$ of incubations. The same uppercase letter indicates values are not significantly different among treatments $(P<0.05)$ within a same incubation period. The same lowercase letter indicates values are not significantly different between two periods $(P<0.05)$ with the same treatment. The error bars stand for standard deviations of the means $(n=3)$.

\section{Discussion}

In this study, inorganic $\mathrm{N}\left(\mathrm{NH}_{4}^{+}-\mathrm{N}\right.$ and $\left.\mathrm{NO}_{3}^{-}-\mathrm{N}\right)$ and ON concentrations as well as the ${ }^{15} \mathrm{~N}$ atom $\%$ of $\mathrm{NO}_{3}$ $-\mathrm{N}$ decreased over the course of the incubation, while ${ }^{15} \mathrm{~N}$ atom $\%$ of $\mathrm{NH}_{4}^{+}-\mathrm{N}$ and $\mathrm{ON}$ increased with time. The characteristics of soil $\mathrm{N}$ concentrations along time were in line with some previous investigations (Yin et al., 2002; Scott et al., 2008; Lu et al., 2015). It is widely believed that $\mathrm{NH}_{4}^{+}-\mathrm{N}$ is an important product of DNRA (Rütting et al., 2011; Giblin et al., 2013), and the $\mathrm{NH}_{4}^{+}-\mathrm{N}$ generated from DNRA can be converted into other $\mathrm{N}$ pools through other processes, one of which is $\mathrm{NH}_{4}{ }^{+}-\mathrm{N}$ immobilization (Tobias et al., 2001; Yin et al., 2002; Zhang et al., 2014). For instance, Tobias et al., (2001) and Yin et al., (2002) claimed that $\mathrm{NH}_{4}^{+}-\mathrm{N}$ generated from DNRA was mainly immobilized in the soil ON pool, while Scott et al., (2008) pointed out that DNRA provided little $\mathrm{NH}_{4}{ }^{+} \mathrm{N}$ to nitrification. As the microorganisms were stimulated by exogenous $\mathrm{C}$ sources, $\mathrm{NH}_{4}^{+}-\mathrm{N}$ immobilization might be enhanced, which would accelerate the consumption of $\mathrm{NH}_{4}^{+}-\mathrm{N}$ (Yin et al., 2002). Therefore, $\mathrm{NH}_{4}^{+}-\mathrm{N}$ in soils amended with $\mathrm{OC}$ decreased rapidly in contrast with that in NC. In addition, as a major reactant of DNRA as well as other $\mathrm{NO}_{3}^{-}$reduction 
processes, $\mathrm{NO}_{3}^{-}-\mathrm{N}$ was continuously consumed and transformed into other $\mathrm{N}$ pools such as $\mathrm{NH}_{4}^{+}-\mathrm{N}, \mathrm{ON}$, $\mathrm{N}_{2}$ and $\mathrm{N}_{2} \mathrm{O}$. Different $\mathrm{OC}$ sources also affected $\mathrm{NO}_{3}$ -N consumption rate, possibly through influencing activities of enzyme and/or microorganisms (Bonin et al., 1999). However, the $\mathrm{NO}_{3}^{-}-\mathrm{N}$ concentrations did not decrease drastically while the atom $\%$ of $\mathrm{NO}_{3}-{ }^{-15} \mathrm{~N}$ did, indicating that nitrification was occurring during incubations, which generated $\mathrm{NO}_{3}-{ }^{-14} \mathrm{~N}$ and diluted the $\mathrm{NO}_{3}-{ }^{-15} \mathrm{~N}$ pool. Furthermore, Rice and Tiedje (1989) pointed out that $\mathrm{NO}_{3}{ }^{-}$assimilation could be inhibited by $60 \%$ and $80 \%$ under low $\left(0.1 \mathrm{mg} \mathrm{N} \mathrm{kg}^{-1}\right.$ dry soil $)$ and higher soil $\mathrm{NH}_{4}^{+}-\mathrm{N}$ concentrations $\left(10 \mathrm{mg} \mathrm{N} \mathrm{kg}^{-1}\right.$ dry soil), respectively. In this study, $\mathrm{NH}_{4}^{+}-\mathrm{N}$ concentrations in most treatments were higher than $10 \mathrm{mg}$ $\mathrm{N} \mathrm{kg}^{-1}$ dry soil over the 24-h incubations, hence $\mathrm{NO}_{3}^{-}$ assimilation was probably inhibited and the formed $\mathrm{ON}-{ }^{15} \mathrm{~N}$ might come from $\mathrm{NH}_{4}^{+}-\mathrm{N}$ immobilization. The low $\mathrm{NH}_{4}^{+}{ }^{+}{ }^{15} \mathrm{~N}$ atom\% also indicated that $\mathrm{NH}_{4}{ }^{+}-$ ${ }^{15} \mathrm{~N}$ generated through DNRA probably converted into the ON pool.

Different OC additions significantly increased soil DNRA rates during the first 12-h incubation in the present study. As a common exogenous OC source, glucose has been widely selected to estimate the effect of $\mathrm{C}$ on soil DNRA process, whereas the existing results of its effect on DNRA are contradictory. Some studies demonstrated that the addition of glucose could support respiration as well as fermentation, thus stimulating DNRA (Buresh and Patrick, 1978; Yin et al., 2002). However, DeCatanzaro et al., (1987) and Chen et al., (1995) found that the addition of glucose did not influence soil DNRA. Some other publications also indicated that other $\mathrm{C}$ sources such as straw, glycerol, methanol and succinate had little effects on soil DNRA process (Buresh and Patrick, 1978; Yin et al., 1998). Buresh and Patrick (1978) and Yin et al., (1998) attributed these findings to the fact that the mentioned $\mathrm{C}$ sources were poor substrates for fer- mentation. However, there are three distinct pathways of microbial DNRA when available reductants such as sulfide and reduced iron are present, fermentative DNRA, respiratory DNRA and Chemoautotrophic DNRA (Roberts et al., 2014). Hence, it is possible that the above mentioned $\mathrm{C}$ sources did not favor the three DNRA pathways controlled by the species of soil bacteria. In the present study, additions of glucose significantly increased soil DNRA rates compared with the NC treatment, indicating that bacteria involving in the DNRA process exist in the collected sediments of Chongming Dongtan wetland. Nevertheless, what kind of DNRA bacteria dominated the process are still unclear and deserve further investigations.

Low molecular organic acids are commonly present and important factors in affecting transformation and transfer of heavy metals in terrestrial ecosystems (Schwab et al., 2008), but their effects on simulating soil DNRA are still unknown. Results of this study indicate that the four organic acid treatments have positive effects on soil DNRA, and the effects on enhancing soil DNRA rate follows the order: $\mathrm{OL}>\mathrm{CT}>\mathrm{AT}>\mathrm{ML}$. The differences are presumably caused by the different decomposition rates of organic acids. In general, organic acids are decomposed by microorganisms through two pathways, oxidation and decarboxylation (McCollom et al., 2003). Some studies indicated that the decomposition rates of citrate and oxalate were faster than acetate (Jones et al., 2001; Hees et al., 2002). The fast degradations could rapidly provide energy for soil DNRA (Morley and Baggs, 2010). When the organic acids were almost entirely decomposed by soil microorganisms, the decomposition rates would be stable (Jones, 1998). Consequently, the soil DNRA rates in OL and CT were significantly higher than that in AT over the 12-h incubation, while they were higher in AT rather in than OL and CT over the second 12-h incubation. Nevertheless, whether soil DNRA rate is associated to the 
decomposition rate of $\mathrm{OC}$ is still unclear and need further study. In the Chongming Dongtan wetland, the proportion of vegetation coverage area to total area is high (Gan et al., 2009). Large root exudates and plant residues may lead to high concentrations of soil organic acids. Consequently, glucose may not be the most appropriate $\mathrm{C}$ source for understanding the regulation of soil DNRA capacity in situ.

In treatment $\mathrm{NC}$, the relative potential of DNRA was about $5 \%$ which was in agreement with some previous studies (Tobias et al., 2001; Yin et al., 2002), implying that the SOC was limiting for soil DNRA, possibly due to lack of energy. Moreover, additions of ${ }^{15} \mathrm{~N}$ increased concentrations of soil $\mathrm{NO}_{3}^{-}-\mathrm{N}$ as well, which created low $\mathrm{C} / \mathrm{NO}_{3}^{-}$ratios in $\mathrm{NC}$ soils. It is widely accepted that the low $\mathrm{C} / \mathrm{NO}_{3}{ }^{-}$ratio is unfavorable for DNRA (Rütting et al., 2011), thus the DNRA process must be weak in $\mathrm{NC}$ treatment. However, the effects of $\mathrm{C} / \mathrm{NO}_{3}^{-}$with different $\mathrm{OC}$ sources on soil DNRA are still unclear and need to be investigated in the future. In addition, soil $\mathrm{NH}_{4}^{+}-{ }^{15} \mathrm{~N}$ and $\mathrm{ON}-{ }^{15} \mathrm{~N}$ atom $\%$ showed little increase over the second 12-h incubation, thus induced low soil DNRA rates in alltreatments. This result demonstrated that DNRA was a fast process in soils, which was in consistent with some previous studies (Yin et al., 2002; Lu et al., 2013).

\section{Conclusion}

In this study, the effects of various $\mathrm{C}$ sources on soil DNRA rate were estimated using the ${ }^{15} \mathrm{~N}$ tracer technique. After the $24 \mathrm{~h}$ incubation, the results showed that concentrations of inorganic $\mathrm{N}, \mathrm{ON}$ as well as the ${ }^{15} \mathrm{~N}$ atom $\%$ of $\mathrm{NO}_{3}^{-}-\mathrm{N}$ werw lower compared with the initial values, while ${ }^{15} \mathrm{~N}$ atom $\%$ of $\mathrm{NH}_{4}^{+}-\mathrm{N}$ and $\mathrm{ON}$ showed increasing tendencies, indicating that DNRA, DNF, inorganic $\mathrm{N}$ immobilization and $\mathrm{ON}$ mineralization occurred during the incubation periods. Over the first 12-h incubation, soils with OL and CT exhibited greater soil DNRA rates as well as the relative potential of soil DNRA than that with GC, demonstrating that organic acids have different impacts on soil DNRA from glucose. The reason might be the different decomposition rates of various OC compounds influencing the available energy provided for DNRA microorganisms. In contrast, soils with no addition of exogenous $\mathrm{C}$ showed lower soil DNRA rates, presumably due to the lack of available energy and the low $\mathrm{C} / \mathrm{NO}_{3}^{-}$ratio. In addition, soil DNRA rates over the 12-h incubation were significantly higher than those over the 24-h incubation, demonstrating again that DNRA is a fast process. These findings indicate that soil DNRA can be regulated by different OC sources, suggesting that only taking glucose as $\mathrm{C}$ source may not reflect the soil DNRA capacity well in the field. In the future, more attention should be paid to investigate how soil $\mathrm{pH}$, different quantities of various $\mathrm{OC}$ types as well as $\mathrm{C} / \mathrm{NO}_{3}^{-}$ratio with different $\mathrm{OC}$ types affect soil DNRA process.

\section{Acknowledgements}

This study was financially supported by the National Natural Science Foundation of China (41375149).

\section{References}

Baggs, E.M. 2008. A review of stable isotope techniques for $\mathrm{N}_{2} \mathrm{O}$ source partitioning in soils: recent progress, remaining challenges and future considerations. Rapid Commun. Mass Sp. 22, 1664-1672.

Bai, J.H., Gao, H.F., Xiao, R., Wang, J., Huang, C. 2012. A review of soil nitrogen mineralization as affected by water and salt in coastal wetlands: issues and methods. CLEAN-Soil Air Water. 40, 1099-1105. 
Bonin, P., Omnes, P., Chalamet, A. 1999. The influence of nitrate and carbon inputs on the end products of bacterial nitrate dissimilation in marine sediment. Toxicol. Environ. Chem. 73, 67-79.

Buresh, R.J., Patrick, W.H. 1978. Nitrate reduction to ammonium in anaerobic soil. Soil Sci. Soc. Am. J. 42, 913-918.

Burgin, A.J., Hamilton, S.K. 2007. Have we overemphasized the role of denitrification in aquatic ecosystems?. A review of nitrate removal pathways. Front Ecol. Environ. 5, 89-96.

Chen, D.L., Chalk, P.M., Freney, J.R. 1995. Distribution of reduced products of ${ }^{15} \mathrm{~N}$-labelled nitrate in anaerobic soils. Soil Biol. Biochem. 27, 15391545 .

Francis, C.A., Beman, J.M., Kuypers, M.M. 2007. New processes and players in the nitrogen cycle: the microbial ecology of anaerobic and archaeal ammonia oxidation. ISME J. 1, 19-27.

Gan, X.J., Cai, Y.T., Choi, C.Y., Ma, Z.J., Chen, J.K., Li, B. 2009. Potential impacts of invasive Spartina alterniflora on spring bird communities at Chongming Dongtan, a Chinese wetland of international importance. Estuar. Coast. Shelf S. 83, 211-218.

Giblin, A.E., Tobias, C.R., Song, B., Weston, N., Banta, G.T., Rivera-Monroy, V.H. 2013. The importance of dissimilatory nitrate reduction to ammonium (DNRA) in the nitrogen cycle of coastal ecosystems. Oceanography. 26, 124-131.

Gong, P., Zhang, L., Wu, Z., Shang, Z., Li, D. 2013. Does the nitrification inhibitor dicyandiamide affect the abundance of ammonia-oxidizing bacteria and archaea in a Hap-Udic Luvisol?. J. Soil Sci. Plant Nut. 13, 35-42.

Henderson, S.L., Dandie, C.E., Patten, C.L., Zebarth, B.J., Burton, D.L., Trevors, J.T., Goyer, C. 2010. Changes in denitrifier abundance, denitrification gene mRNA levels, nitrous oxide emissions, and denitrification in anoxic soil microcosms amend- ed with glucose and plant residues. Appl. Environ. Microb. 76, 2155-2164.

Jones, D.L. 1998. Organic acids in the rhizosphere-a critical review. Plant Soil. 205, 25-44.

Jones, D.L., Eldhuset, T., de Wit, H.A., Swensen, B. 2001. Aluminium effects on organic acid mineralization in a Norway spruce forest soil. Soil Biol. Biochem. 33, 1259-1267.

Koop-Jakobsen, K., Giblin, A.E. 2010. The effect of increased nitrate loading on nitrate reduction via denitrification and DNRA in salt marsh sediments. Limnol. Oceanogr. 55, 789-802.

Lai, F.S., Friedlander, S.K., Pich, J., Hidy, G.M. 1972. The self-preserving particle size distribution for Brownian coagulation in the free-molecule regime. J. Colloid Interf. Sci. 39, 395-405.

Li, Y.L., Wang, L., Zhang, W.Q., Zhang, S.P., Wang, H.L., Fu, X.H., Le, Y.Q. 2010. Variability of soil carbon sequestration capability and microbial activity of different types of salt marsh soils at Chongming Dongtan. Ecol. Eng. 36, 1754-1760.

Lu, W.W., Zhang, H.L., Shi, W.M. 2013. Dissimilatory nitrate reduction to ammonium in an anaerobic agricultural soil as affected by glucose and free sulfide. Eur. J. Soil Biol. 58, 98-104.

Lu, W.W., Zhang, H.L., Min, J., Shi, W.M. 2015. Dissimilatory nitrate reduction to ammonium in a soil under greenhouse vegetable cultivation as affected by organic amendments. J. Soil. Sediment. $15,1169-1177$.

McCollom, T.M., Seewald, J.S. 2003. Experimental study of the hydrothermal reactivity of organic acids and acid anions: II. Acetic acid, acetate, and valeric acid. Geochim. Cosmochim. Ac. 67, 36453664.

Moreno-Vivián, C., Ferguson, S.J. 1998. Definition and distinction between assimilatory, dissimilatory and respiratory pathways. Mol. Microbiol. 29, 664-666. 
Morley, N.J., Baggs, E.M. 2010. Carbon and oxygen controls on $\mathrm{N}_{2} \mathrm{O}$ and $\mathrm{N}_{2}$ production during nitrate reduction. Soil Biol. Biochem. 42, 1864-1871.

Morley, N.J., Richardson, D.J., Baggs, E.M. 2014. Substrate Induced Denitrification over or under Estimates Shifts in Soil $\mathrm{N}_{2} / \mathrm{N}_{2} \mathrm{O}$ Ratios. PloS One. 9, e108144.

Pett-Ridge, J., Silver, W.L., Firestone, M.K. 2006. Redox fluctuations frame microbial community impacts on N-cycling rates in a humid tropical forest soil. Biogeochemistry. 81, 95-110.

Rabalais, N.N., Nixon, S.W. 2002. Nutrient overenrichment in coastal waters: global patterns of cause and effect. Estuarine Research Federation.

Rice, C.W., Tiedje, J.M. 1989. Regulation of nitrate assimilation by ammonium in soils and in isolated soil microorganisms. Soil Biol. Biochem. 21, 597-602.

Roberts, K.L., Kessler, A.J., Grace, M.R., Cook, P.L.M. 2014. Increased rates of dissimilatory nitrate reduction to ammonium (DNRA) under oxic conditions in a periodically hypoxic estuary. Geochim Cosmochim Ac. 133, 313-324.

Rütting, T., Boeckx, P., Müller, C., Klemedtsson, L. 2011. Assessment of the importance of dissimilatory nitrate reduction to ammonium for the terrestrial nitrogen cycle. Biogeosciences. 8, 1779-1791.

Schwab, A.P., Zhu, D.S., Banks, M.K. 2008. Influence of organic acids on the transport of heavy metals in soil. Chemosphere. 72, 986-994.

Scott, J.T., McCarthy, M.J., Gardner, W.S., Doyle, R.D. 2008. Denitrification, dissimilatory nitrate reduction to ammonium, and nitrogen fixation along a nitrate concentration gradient in a created freshwater wetland. Biogeochemistry. 87, 99-111.

Silver, W.L., Herman, D.J., Firestone, M.K. 2001. Dissimilatory nitrate reduction to ammonium in upland tropical forest soils. Ecology. 82, 24102416.
Tiedje, J.M. 1988. Ecology of denitrification and dissimilatory nitrate reduction to ammonium. Biolo. Anaero. Microorganisms. 717, 179-244.

Tobias, C.R., Macko, S.A., Anderson, I.C., Canuel, E.A., Harvey, J.W. 2001. Tracking the fate of a high concentration groundwater nitrate plume through a fringing marsh: a combined groundwater tracer and in situ isotope enrichment study. Limnol. Oceanogr. 46, 1977-1989.

Yin S.X., Shen, Q.R., Tang, Y., Cheng, L. 1998. Reduction of nitrate to ammonium in selected paddy soils of China. Pedosphere. 8, 221-228.

Yin S.X., Chen, D., Chen, L.M., Edis, R. 2002. Dissimilatory nitrate reduction to ammonium and responsible microorganisms in two Chinese and Australian paddy soils. Soil Biol. Biochem. 34, 1131-1137.

Zhang, J.B., Lan, T., Müller, C., Cai, Z.C. 2015. Dissimilatory nitrate reduction to ammonium (DNRA) plays an important role in soil nitrogen conservation in neutral and alkaline but not acidic rice soil. J. Soil. Sediment. 15, 523-531.

Zhang, S.P., Wang, L., Hu, J.J., Zhang, W.Q., Fu, X.H., Le, Y.Q., Jin, F.M. 2011. Organic carbon accumulation capability of two typical tidal wetland soils in Chongming Dongtan, China. J. Environ. Sci.-China. 23, 87-94.

Zhao, H.F., Yao, X.J., Wang, Q., Chen, Y.S., Xu. X.N. 2013. Nitrogen deposition and soil nitrogen dynamics in subtropical evergreen broad-leaved stands along an age-sequence. J. Soil Sci. Plant Nut. 13, 237-250.

Zumft, W.G. 1997. Cell biology and molecular basis of denitrification. Microbiol. Mol. Biol. R. 61, 533-616. 